\title{
RETRACTED ARTICLE: Initial Validation of the Caregiver Wish List for Parenting Practices
}

Jill Thijssen · Corine de Ruiter

Published online: 13 April 2011

(C) The Author(s) 2011. This article is published with open access at Springerlink.com

The author has withdrawn this paper.

J. Thijssen $(\bowtie) \cdot$ C. de Ruiter

Department of Clinical Psychological Science, Maastricht

University, P.O. Box 616, 6200 MD Maastricht, The Netherlands

e-mail: Jill.Thijssen@ maastrichtuniversity.nl 